\title{
From a Traditional to a Networking Organization: The Role of Information and Communication Technologies
}

\author{
Jerzy Kisielnicki \\ Warsaw University, Faculty of Management, Warsaw, Poland
}

\author{
jerzy@kisielnicki.edu.pl jkisielnicki@wz.uw.edu.pl
}

\begin{abstract}
The development of Information and Communication Technologies (ICT) resulted in transforming the traditional hierarchical organizations into networking flexible ones. In the circumstances of identifying a new type of organizations, the notions as 'organization' and 'synergy' should be revised. The organizations with individual elements that build up a network have altered their attitude towards the problem of a global optimum. Individual elements that can be called 'junctions,' strive to optimize local optima instead of the traditionally approached global optimum. The article offers a hypothesis that a networking organization is formed when all its elements gain profits. What is needed to form it is the consensus of all the constituent elements. The management of networking organization is supported by the contemporary ICT tools that help to manage the network. Intellectual capital is the most important element of a networking organization. A new organizational form is becoming fully competitive against traditional organizations with the fixed position in the market. A comparison of the model of business functioning of a traditional and a networking organization has been made. The model shows what economic conditions should be met to form networking organizations. It presents as well practical examples of relations between traditional and networking organizations. The suggested further research into the issue has been outlined in the text.
\end{abstract}

Keywords: management, Information and Communication Technology, traditional organization, networking organization, synergy, global optimum, local optimum.

\section{Introduction}

The article dwells upon the changes going on in the functioning of an organization in terms of the Information and Communication Technologies (ICT) development. The contemporary ICT channeled the founding of networking organizations, i.e. the forming of new opinions on paradigms

'organization' and 'synergy.' Within the

Material published as part of this publication, either on-line or in print, is copyrighted by the Informing Science Institute.

Permission to make digital or paper copy of part or all of these works for personal or classroom use is granted without fee provided that the copies are not made or distributed for profit or commercial advantage AND that copies 1) bear this notice in full and 2) give the full citation on the first page. It is permissible to abstract these works so long as credit is given. To copy in all other cases or to republish or to post on a server or to redistribute to lists requires specific permission and payment of a fee. Contact Publisher@,InformingScience.org to request redistribution permission. new conditions of founding networking organizations and ICT development, these traditional notions originating in the systems theory, need to be revised. This in particular concerns the naming of organizations that we treat as superior to the notion 'synergy.' In the management sciences there exist widely applied terms formulated by the founders of the systems theory, i.e., L. von Bertalanffy 
(1968), A. Backlund (2000), B. Wilson (2000). According to the systems theory, the management sciences apply a paradigm that claims that an organization is a system where constituent elements (sub-systems) work for the good of the whole (a global optimum). As a consequence, an organization is gaining a total effect higher than in case of summing up individual effects of constituent elements (sub-systems). The adopting of this paradigm justifies the approach that what is important is a global optimum while local optima for individual elements of an organization are not so significant. What is important is the organization as a whole. It works according to a marketing motto of 'a big can do more.' As a consequence, what is desirable is such a state where the system of power and knowledge transfer is available for the whole organization. The fact that individual elements of the organization may report a loss is of smaller importance.

\section{Networking Organization Concept}

Development of ICT created a new type of organizations that is networking organizations. The networking organizations, with their individual elements building up a network, reported an altered attitude towards a global optimum. Individual elements that can be called junctions, strive to optimize local optima. The product of the whole organization is not so important for individual elements of a networking organization. In a new situation, a networking organization is founded only when it is profitable for all constituent elements (junctions) (see J. Kisielnicki, ed., 2008). As we are going to demonstrate further on, these elements of the organization that have not reported direct profit, show resistance to the automatic founding of an organization that ignores their new situation. The unfamiliarity with a new paradigm to the effect that an organization is founded only when its all elements gain profit frequently provokes strong resistance to forming a new organization. Many newly established corporations report conflicts that are sometimes quite serious. A hypothesis can be formulated to the effect that a networking organization as a contemporary type of an organization is founded only when all constituent elements gain profit on its being founded. In other words, the founding of a networking organization requires a consensus on the part of all constituent elements. The networking organization management infrastructure is provided by contemporary tools offered by ICT, and particularly that support the network management.

There is no generally accepted definition of the notion of a networking organization. In the literature it is frequently defined by its properties. D. Kirpatrick (2011) as well as G. Hamel (2007, 2011) analyze organizations from the angle of management. They claim that the future of management lies in self-governed teams oriented towards a fast and effective communication and competences development. A networking organization should work in this way.

We assume that a networking organization is voluntarily founded by different type of organizations. The organizations set up unions, which is facilitated by ICT. The aim of such unions is to bring profits for all the participants. The profit of individual elements (organizations) should be higher than in case of individual organizations forming networking organizations acted in a traditional way. The duration of a union is fixed by an organization that as the first sees the further existence of the union as unfavorable. The remaining organizations may continue a networking union if they deem it purposeful. A new union, also a networking one, continues to function without the organization that left it. These new systems may enter into unions with other organizations. As a consequence, a brand new networking organization is founded. The key property of a networking organization is the swiftness of operation offering a possibility to adjust to the new conditions of the 'changing world.' Internet gives this ability, therefore it can be ascertained that this organization is a 'child' of global computer networks.

According to the above, a networking organization is the organization that meets the following criteria: 
- founded voluntarily, with its members forming different unions to accomplish a common purpose,

- duration of an union is fixed by each of members of the organization. The decision on its dissolution can be made by a member who as a first resolves the existence of the union and leaves it,

- organization functions in cyberspace. The cyberspace is determined by the following two basic elements:

- computer systems situated in different places of physical space, able to receive or send information,

- global computer networks able to carry the information, or enabling communication among the existing computer systems.

The relations among the elements of a networking organization assume the form of various ties determined by the adopted communication procedures and protocols and the legislation in force. The latter is not always adjusted to the changing world. A particular property of cyberspace is its multidisciplinary character of ties and impossibility to define its boundaries through physical measurements.

\section{On Certain Practical Aspects of the Functioning of a Networking Organization}

I would like to present examples of three different behaviors of organizations in the real world. There was no permission to provide detailed figures however the presentation will concern behaviors of organizations within the process of changes.

The examples demonstrate that an ignorance of business proceedings differences between networking and traditional organizations causes conflicts that sometimes need an intervention of high-ranking state administration. After some time, decision-makers became aware of their wrong decisions and in a consequence conflicts were settled. Finally they decided to build one networking organization instead one traditional organization. Therefore they could achieve less profit. However the less profit is compensated with savings and higher efficiency in unit networking organizations. Additionally, managers, working in networking organizations, were more efficient than in a big traditional corporation. Communication channels have been shortened and managers were closer to their teams and workers.

Examples contain many different relations between traditional and networking organizations. Particular attention is paid to Example I for which the mathematical business model (MBM) is presented. Using this model we can calculate funds required by the mining company in order to prevent them from closing. This funding has been used to build one company consisting of 14 plants belonging to the mine. Example II shows a transformation of the traditional company into networking organization. Example III shows people resistance to change what did not allow building a networking organization. For this example MBM is presented as a general model only due to a lack of permission for detailed data publication.

Example I. Complex coal mines. Fourteen mines in a networking organization. Certain aspects of the price policy and coal export solutions were a subject of negotiations. The mines had different owners, including the State Treasury. The coal quality and technical conditions of mining varied in individual mines. The organizational structure was transformed in 2012. The mines were taken over by one owner who introduced a hierarchical management system, typical for traditional organizations. Therefore, a networking organization was replaced with a traditional one. The economic calculation showed that the closing-up of one mine would bring profit to the newly formed 
organization (now composed of 13 mines). The workforce of the closing-up mine refused to agree to the liquidation and staged an underground protest. Miners working in 13 mines threatened with a solidarity strike. As a result of multilateral many-hour negotiations with the presence of the Prime Minister, a solution was adopted requiring putting capital into the 14th mine. The social respects forced decision resulted in a lower profit of the whole system of 14 mines. In the new circumstances of coming back to the networking management system there is no social tension. Each mine is profitable. Obviously it was not the best solution from the owner's point of view. However, leaving the traditional management system would entail considerable economic losses and social unrest. (Author's own elaboration is based on data from the Ministry of Economy PR2014).

Example II. Sugar factories in a certain region of the country worked independently. All seven plants had traditional management systems. Their economic results differ in different years. Despite the various threats, factories managed to coordinate work and they formed a networking organization. They settle accounts and distribute the gained profits according to the algorithm accepted by all sugar plants. Each plant is an element of the networking organization. Although the networking organization system has operated for five years, every year individual plants reported beneficial results. The networking organization consists of marketing, sales, training, legal, operation departments and ITC development department (including one set of information, or data warehouses). (Author's elaboration is based on experts' opinions prepared for the Sugar Industrial Group, 2011-2013).

Example III. Ministry of Science and Higher Education in Poland decided to launch a universal open hosting and communication platform for networking of knowledge resources of science, education and open knowledge society throughout the country. The platform was a starting point for building a nation-wide scientific and technical information system. Therefore, a traditional organization was established, consisting of 17 scientific centers selected from the best universities. The activity of the newly established traditional organization failed. Universities did not want their groups of researchers let go. They even rejected financial bonuses in the form of investments in the infrastructure. Universities are independent administrative bodies. Eventually, they accepted a proposal of establishing networking organization with Universities, implementing SYNAT (in Polish: System Informacji Naukowej i Technicznej), the system of scientific and technological information. The project finished successfully. (Author's elaboration is based on documents of the Ministry of Science and Higher Education, and the SYNAT project; J. Kisielnicki, 2013).

Organizations described above have invested considerable founds on the ICT modernization over the recent three years. The examples show the following shifts: Example I - a networking organization to a traditional one and then coming back to the networking one; Example II - a traditional organization to a networking one; Example III - failure in the establishment of traditional organization and acceptance of a networking form. Therefore, there are many situations where networking organizations are replaced with hierarchical (traditional) ones. In such circumstances a global optimum is replaced with local optima. The management system changes into more flexible one having free transfer of information and knowledge. Networking organizations operate in larger dimensions than traditional ones.

The European Union (EU) can be recognized as a new type of an emerging networking organization. The countries that join it make the decision independently expecting benefits stemming from the membership. In practice, every country joining the UE does it for own benefits. This way we are having an optimization within particular countries (local optima - in network nodes) but not a global optimum within UE. Countries outside the Union fear that a potential membership would deteriorate their political and economic condition. EU does not possess all the properties of a 
networking organization. E.g., it is not possible to leave it freely; it also has authorities that may take certain decisions in the Member States.

\section{The Paradigm of 'Organization' and 'Synergy' Notions in the Context of the Emergence of Networking Organizations and ICT Development}

A paradigm according to T. Khun (1985) means the description of what is shared by all members of a certain scientific discipline, and exclusively by them. And vice versa; the sharing of a common paradigm makes a group of somehow dispersed people be such a discipline. A paradigm as such is a collection of notions and theories forming foundations for a certain science. Theories and notions that form a paradigm are rather unquestionable; at least until a paradigm is cognitively creative. It also means 'a model.' A paradigm can be treated as a well-ordered collection of beliefs, approaches or assumptions shared by scientists of a given discipline. A paradigm can be also described as a model scientific achievement shared by a certain scientific community as well as the process of scientific cognition itself. Therefore, it is a model, multimodal methodological approach adopted by a certain community of practitioners. What is important for us is an ontological aspect of a paradigm. The ontological models reflect an intrinsic structure and the ways of functioning of a part of reality under study. It is believed that out of a collection of paradigms pertaining to management sciences, two notions: of 'organization' and 'synergy' need being revised. These two paradigms are linked with the generally ruling systems approach.

The classical literature on management sciences argues, similarly to T. Kotarbiński (1975), that an organization is a kind of the whole determined by the attitude of its constituent elements to itself. Therefore, it is the whole where all the components co-work to bring about the success of the whole. Similar descriptions of an organization are offered by A.F. Stoner and C. Wankel (2005), K.C. Loudon and J.P. Loudon (2010), and R.W. Griffin (2013). In other words, an organization can be seen as a certain hierarchical structure directed towards accomplishing a purpose or purposes. These rules, however, do not work in the conditions of emerging a new type of organizations, namely networking organizations. The setting up of a new type of an organizational system, i.e. networking organizations, offers a revised approach to the issues of the contemporary management theory. In networking organizations we can recognize new values absent in the traditional organizations. This, however, poses new threats.

The analysis of the notion 'organization' requires a closer look at how one of the most popular paradigms, i.e. synergy functions in traditional and networking organizations.

Synergy means such cooperation of an organization and its elements that is more effective than the sum of their separate actions. The phenomenon of synergy can be described as the one where the elements constituting a system, here: an organization, give a result somehow higher than a simple sum of effects produced by each separate factor. Therefore, synergy is a universal prerogative operating everywhere in micro- and macro-management.

What entitles us to claim that the two paradigms function not always according to the rules of the classical management theory? It is the paradigm of synergy that is a spirit's movement of establishing organizations. The classical management theory argues that in an organization each of its constituent elements faces a task to act for the good of the whole. This does not concern a networking organization. Such organization is established to contribute to the success of all the elements that form it. As practice shows, individual entities forming networking organizations are interested above all in what will they gain on the establishment of the organization and then in what will the established organization achieve as a whole. Some directions of applying ICT in management sciences resulted in the presently referred to 'new face of management' with a net- 
working organization as one of its images. The description of a network is one of the most important ideas behind the coining of the organization science (M. Castells, 1996). The term of a 'networking organization' was popularized by P. Drucker (1998), R.E. Miles and C.C. Snow (1992), A.I. Oliver and M. Ebers (1998) inter alia. The functioning of a networking organization requires different management mechanisms than those in traditional organizations. It has to be accentuated, however, that the term of a 'networking organization' is not popular. P. Senge (1990) refers to such type of organizations as the 'learning organizations.' Meanwhile, M. Hammer, J. Champy (1994) call them 're-engineering organizations,' and J.B. Quinn, (1992) - 'intelligent organizations.' There also exists the term 'virtual organizations.' The authors who apply it claim that the term 'virtual' originates in the Latin words of 'virtualis,' i.e. effective, and 'virtus,' i.e. might. 'Virtual' also means theoretically existable; see J.A. Byrne, R. Brandt (1993); W. Davidow, M. Malone (1992); W. Faisst (1997); J. Kisielnicki, ed., (2008). The analyzed type of a new organization may be included in the class of emerging organizations, i.e. the so-called emergent systems (L. Markus, A. Majchrzak, L. Gasser, 2002).

Addressing a traditional organization as a system we are talking about the rules of synergy. The total result of the functioning of the whole organization is higher than the sum of the results of separately functioning elements. That is why there are frequent situations when individual organizational elements being the parts of a larger traditional organization report losses, but due to the effect of synergy, the whole (the organization) scores a success. Such a situation has been described earlier in three examples.

A networking organization gives synergy effects too, however the most important is that each constituent element can gain profit for itself. If it does not report profits, or does not expect reporting them, it does not form it, i.e. does not enter the organizational system. That is why a networking organization can be called an egoistic organization in a good sense of the term. The intellectual capital is the most important element of a networking organization. If the managing staff shows unique competences and relevant intellectual capital while forming a network organization, it may make a new organizational form becoming fully competitive towards traditional organizations with the fixed position in the market and higher financial assets. This way the interconnected small organizations may become fully competitive towards even the largest organizations. Each entity being a component of a network organization should show unique competences to testify it is an attractive partner, i.e., it offers what others cannot for the common good. In network organizations, contrary to traditional ones, there exists the notion of 'distance.' Elements forming a network organization as well as its clients are as far from one another as one 'click.' One can say that one's organization is where one's computer (laptop) is, and frequently the ICT development suffices it to have a multifunction cellular phone (smartphone). The effectiveness of organization's performance is strongly determined by issues linked with the knowledge transfer and moral standards of the managing staff and employees of such an organization. High moral standards and entailing trustworthiness are in our opinion the key elements that determine the effective functioning of networking organizations (J. Kisielnicki, 2008).

\section{A Networking Organization as a New Form of Organization's Functioning}

Founding and functioning of a networking organization was channeled by the ICT development. This technology helps improve the management and offers ever more effective tools. In management it is common to strive to make decisions by applying the following communication chain:

$$
\text { D (data) - I (information) - K (knowledge) - W (wisdom) }
$$

We may acknowledge that information plays a key position in this chain. It assumes different forms, frequently being processed (knowledge, wisdom), or raw (data). The information in man- 
agement is treated as idiosyncratic resources that help solve a wide range of problems. Management deals with issues linked with decision making while the application of information and knowledge means solving various problems pertaining to the functioning of individual entities in the conditions of shortages of such resources as soil, workforce, capital and entrepreneurship. Decisions made in these domains should heed practical, unlimited needs of society. To meet these needs, or to face the problem of shortages, different decision making procedures are being applied. They in turn help settle the question of the allocation of the resources. The contemporary theory of management sciences, supporting in this field economics sciences, deals with the process of making decisions aimed to obtain a way the contemporary society should face problems stemming from the phenomena of shortages of resources, including information and knowledge.

The information and knowledge management is the essence of the contemporary phase of the development of management sciences. That is why it seems that we are witnessing the emergence of a new stage of the development of the management sciences discipline that can be referred to as the information and knowledge management school. The knowledge-based organization is not only a state that should be achieved, but also the continuous process that should be progressively developed. According to Z. Gackowski (2012), the knowledge development proceeds along an ascending and expanding spiral from primary information, through factual data, secondary information and data, knowledge and concepts to the still blurred notion of wisdom. This is concordant with the ascertainment that the future of the decision making theory lies in the implementation of an economic model based on information and knowledge. The ICT, and especially computer networks, gives us possibility to find networking organizations as global organizations applying information and knowledge management and ever more advanced tools supporting the decision making processes.

The contemporary global organization, assuming it is a networking organization, functions in cyberspace. Here the time of information transfer and sharing knowledge, as well as the duration of the decision making process, is very short and frequently expressed as microseconds. From the wide range of tools accessible to contemporary managers and executives the following new possibilities offered by ICT should be mentioned:

- the setting up of global information networks, e.g., the Internet, enabling the creation of new organizational forms for different branches, such as e-trade, e-learning, e-banking, eadministration,

- access to large information resources and to large dispersed data bases and data warehouses and knowledge bases enabling the information and knowledge transfer in unprecedented alignments at unprecedented speed and intensity,

- tools supporting management, e.g., MIS (Management Information System) advisory systems, and in particular ERP (Enterprise Resource Planning) and BI (Business Intelligence) complex services.

The development of the ICT-related tools is aided by the cloud computing technology (T. Velte, R. Velte, 2009; B. Rosenberg, 2014). Nevertheless, as noted by R.S. Burt (2005), due to cultural limitations the capacity of networks and the functioning of networking organizations are not fully used.

\section{Mathematical Business Model (MBM) of a Networking Organization}

The aim of the mathematical business model (MBM) is a formal representation of the situation when we want to transform a traditional organization into a networking one. This situation has been described in the Example I. To prove the hypothesis that the paradigm of synergy works to a 
limited extent in networking organizations, let us compare the business model of the functioning of a networking organization. The model shows what conditions should be met to form networking organizations. We can use it to compute at which profits (in the model named bonuses) traditional organization is willing to enter into coalitions with other organizations and be a part of the network organization.

While considering the business model of a networking organization let us adopt the following dependencies:

$\Omega$ - is a set of all organizations under consideration where $O_{i}$ is an i- exact organization, with $\forall O_{i} \in \Omega$

Each exact organization may form unions (alliances, system).

We may choose between the following:

$\Omega$ complex (a system understood as a subset of cooperating organizations selected from the $\Omega$ set) of networking organizations $W$, where $W_{k} \in W$-is a k- exact networking organization, with $\forall W_{k} \subset \Omega, \quad L\left(W_{k}\right)>1$ where $L\left(W_{k}\right)$ - the size of a networking organization,

$\Omega$ complex (a system understood as a subset of the $\Omega$ set) of traditionally interrelated organizations $T$, where $T_{l} \in T$-is an 1- exact traditional organization, with $L\left(T_{\nu}\right)$ is the size of a traditional organization.

An $O_{i}$ organization cannot simultaneously belong to the complex $W$ and the complex $T$, i.e.

$O_{i} \in T \Rightarrow O_{i} \notin W$

and

$O_{i} \in W \Rightarrow O_{i} \notin T$

The criterion of appraising the organization's functioning is achieving a certain economic effect. In simple terms, we are assuming that such an effect can be provided by an individual profit (there can be, of course, any other effect) of $Z\left(O_{i}\right)$.

An organization that strives to increase profits faces the following options:

1. to increase profit as a result of networking relations - to obtain the profit of $Z_{W k}\left(O_{i}\right)$ - this is the profit of an i- organization when $\forall O_{i} \in W_{k}$,

2. to increase profit through traditional ties - to obtain the profit of $Z_{T l}\left(O_{i}\right)$ - this is the profit of an i- organization when $\forall O_{i} \in T_{l}$.

The following takes place, respectively:

$Z_{W k}\left(O_{i}\right)>Z\left(O_{i}\right.$, and $Z_{T l}\left(O_{i}\right)>Z\left(O_{i}\right)$,

where $\mathrm{Z}\left(\mathrm{O}_{\mathrm{i}}\right)$ means the profit obtained as a result of the independent functioning of the $\mathrm{O}_{\mathrm{i}}$ organization with the absence of any ties and strategic alliances. Otherwise the organization would not seek any change of the hitherto relationships.

An organization strives to obtain the highest possible profit and builds virtual relationships only when its profit of $Z_{W k}\left(O_{i}\right)$ is higher than that in traditional ties, or when it works independently.

The traditionally interrelated organizations do not maximize individual profits (of each organization) but they maximize the total profit for an organization as a whole. 
Calculating total profits we get:

- for traditional organizations

$$
Z\left(T_{l}\right)=\sum_{j=1}^{L\left(T_{l}\right)} Z_{T_{l}}\left(O_{j}\right) \geq \sum_{j=1}^{L\left(T_{l}\right)} Z\left(O_{j}\right) \text { where } \forall j O_{j} \in T_{l}
$$

- for networking organizations

$$
Z\left(W_{k}\right)=\sum_{j=1}^{L\left(W_{k l}\right)} Z_{W_{k l}}\left(O_{j}\right) \geq \sum_{j=1}^{L\left(W_{k}\right)} Z\left(O_{j}\right) \text { where } \forall j O_{j} \in W_{k}
$$

Traditional organizations maximize the profit for an organization as a whole while networking organizations maximize the profit for each constituent organization. Therefore, the following dependencies appear for hypothetical complexes:

- the profit of a complex

$Z(T) \geq Z(W) \vee Z(T)<Z(W)$

- but the profit of an individual organization

$Z_{T_{l}}\left(O_{i}\right) \leq Z_{W_{k}}\left(O_{i}\right)$

A networking organization also strives to maximize the profit over a short time. This results from the fact that the decisions here are being made in rapidly changing conditions. Traditional organizations maximize the profit, too, but within longer periods.

The probability of obtaining profit depends on the following elements, inter alia, (there are, of course, other premises):

- speed and flexibility of adjusting to the changes with the obvious supremacy here on the part of networking organizations,

- the position of an organization in the market with traditional organizations having an advantage over networking ones.

Let us take $P_{n}$ as a probability of earning profit by an organization where $n$ means a factor determining this probability. We are then considering the relationship between $P_{n}\left(Z_{T l}\right)$ and $P_{n}\left(Z_{T k}\right)$. If a probability of earning profit is higher for a traditional organization, the strivings should lead to founding such an organization. However, in the circumstances when at least one of the organizations that can join a traditional organization may earn a higher profit in a networking organization, or:

$$
P_{n}\left(Z_{T l}\left(O_{i}\right)\right)<P_{n}\left(Z_{W k}\left(O_{i}\right)\right)
$$

it refuses to join such traditional organization and strives to form a networking organization. This is irrespective of whether the whole organization under the rule of synergy could obtain profits in the context of its condition before establishing of a network relationship. Nevertheless, depending on a position of the remaining organizations, it can be forced to join a traditional organization.

Possible decision-making situations:

- the $O_{i}$ organization within a networking organization would obtain the profit of $Z W_{i}\left(O_{i}\right)$, $\mathrm{ZW}_{\mathrm{k}}\left(O_{i}\right)$ is the profit of an $\mathrm{i}$ - organization, 
- the $O_{i}$ organization within a traditional organization would obtain the profit of $Z T_{i}\left(O_{i}\right)$, with $Z W_{i}\left(O_{i}\right)>Z T_{i}\left(O_{i}\right)$,

- the remaining organizations that may form a traditional organization with $O_{i}$

$\checkmark$ would obtain the profit of $Z W_{i}\left(O_{i}\right)$ ' within a networking organization,

$\checkmark$ would obtain the profit of $Z T_{i}\left(O_{i}\right)^{\prime}$ within a traditional organization,

$\checkmark$ with the appearance of $Z T_{i}\left(O_{i}\right)^{\prime}>Z W_{i}\left(O_{i}\right)^{\prime}$.

Therefore, these organizations are willing to offer a bonus to the $O_{i}$ organization.

$\checkmark \quad$ let us take $P Z\left(O_{i}\right)_{\mathrm{i}}$ as a bonus for joining a traditional organizations.

If the $O_{i}$ organization does not obtain a bonus of $P Z\left(O_{i}\right)<Z T_{i}\left(O_{i}\right)^{\prime}-Z W_{i}\left(O_{i}\right)^{\prime}$, it will strive to join a coalition of other organizations of the $\Omega$ set that do not belong to the rival $T_{l}$ subset. However, without the $O_{i}$ organization it may happen that a traditional organization fails to achieve the expected effects and such an alliance will be never set up. What we were trying to prove is that the notion of synergy is functioning within a limited boundaries and it is being replaced in this type of unions with the broadly understood notion of profits that are not necessarily economic ones. It can be assumed that the PZ(Oi)i as a bonus for joining a traditional Organizations, is that element which causes changes in redistribution of the expected profit in the networking organization. As described examples show, not always there are clear situations.

In the Example I, a synergy has been reduced by the amount of the effort to invest in 14 mines, which was the situation described in the MBM. However, in Example II, the network organization establishment achieved synergies and helped to survive the crisis in all sugar factories. Example III shows that the creation of a network organization may meet very strong resistance to change in existing traditional organizations. Then there is an obligation to take such decisions, which, although not bring the expected economic effect is synergistic but will operate for the benefit of society. MBM allows simulating different decision variants and choosing the one which might not be an optimal decision however satisfactory decision.

\section{Conclusions and Directions of Future Research}

- Information and communication technologies (ICT) have allowed transforming traditional organizations to new ones. These new organizations are called networking organizations are characterized by eliminating indirect links in information channels and through creating the so-called hubs they enable management decentralization and democratization. In networking organizations performance is optimized in network nodes in the first place. As it was demonstrated with the business model, the planning of basic elements in the economic calculation is carried out in a different way than in case of traditional organizations. In networking organizations there is the primacy of local optimization over the global optimization.

- Owing to the ICT development and access to the Internet, Big Data tools and Cloud Computing technology, the functioning of a networking organization becomes ever more global. If we are striving for fast effects but have limited resources, our strategy should be the founding of networking organizations.

- The limited size of the article makes it difficult to properly dwell upon all the signaled issues. Of course, networking organizations not always attain supremacy over the traditional ones. The speed of making decisions especially in emergencies, as practice shows, is obviously higher in traditional organizations. In a networking organization the decisions should be agreed on thus causing delays. Nevertheless, a hypothesis can be formulated to the effect that with the joint taking decisions in networking organizations there is a larger share of manage- 
ment in the conditions of fuller knowledge than in traditional organizations. The further research is planned to go exactly in this direction.

- In this study, we also observed changes in the management system. It must be highlighted that the role of a manager and methods of management have changed. A manager, due to variable models of functioning, becomes a trainer, not a boss. Management in networking organizations requires high skills, especially in the communication area. This issue will be a subject for a further research.

It has been assumed that the article in this form is a voice in the discussion on the changes in management sciences brought about by the ICT development.

\section{References}

Backlund, A. (2000). The definition of systems. Kybernetes, 29(4), 441-451.

Bertalanffy, L. (1968). General systems theory, fundamental, development, applications. NY.

Burt, R.S. (2005). Brokerage and closure. Oxford: Oxford University Press.

Byrne, J.A., \& Brandt, R. (1993). The virtual corporation. Business Week, 8.02.1993.

Castells, M. (1996). The rise of the network society. Oxford: Blackwell.

Davidow, W., \& Malone M. (1992). The virtual corporation. NY: Harper Business.

Drucker P. (1998). The new organization. Harvard Business Review, 1-2.

Faisst, W. (1997). Information technology as an enabler of virtual enterprises: A life-cycle-oriented description. IT Vision'97. Paderborn: The European Conference on Virtual Enterprises and Networked Solutions.

Faisst, W., \& Birg, O. (1997). Die Rolle des Brokers im Virtuellen Unternehmen und seine Unterstützung durch die Informationsverarbeitung, Arbeitspapier der Reihe. Informations- und Kommunikationssysteme als Gestaltungselement Virtueller Unternehmen, 17/1997. Bern, Leipzig, Nürnberg.

Gackowski, Z. (2012). The helix of human cognition: Knowledge management according to DIKW, E2E, and the proposed view. Informing Science: the International Journal of an Emerging Transdiscipline, 15, 93-119. Retrieved from http://www.inform.nu/Articles/Vol15/ISJv15p093-119Gackowski614.pdf

Griffin, R.W. (2013). Fundamental of organization and management. Warsaw: PEN (in Polish).

Hamel, G. (2007). The future of management. Harvard Business School Press.

Hamel, G. (2011). First, let's fire all the managers. Retrieved from http://hbr.org/2011/12/first-lets-fire-allthe-managers/ar/1

Hammer, M., \& Champy, J. (1994). Reengineering the corporation. Harper Business.

Kirkpatrick, D. (2011). Beyond empowerment: the age of the self-managed organization. Morning Start, Self-Management Institute.

Kisielnicki, J. (1988). Virtual organization as a product of information society. Informatics, 22.

Kisielnicki, J. (Ed.) (2002). Modern organization in virtual communities. London, Beijing: IRMA -Press Hershey.

Kisielnicki, J. (2004). Virtualization as a process of transition of small and medium enterprise in the global virtual organization. In M. W. L. Fong (Ed.), E-Collaborations and Virtual Organizations (pp. 184205). London: IRM Press Hershey.

Kisielnicki J. (Ed.) (2008). Virtual technologies, concepts, methodologies, tools, and applications. NY: ISR Hershey. 
Kisielnicki, J. (2014). The concept of the organization in the light of the development of information and communication technology (ICT). Organization and Management, 1A (159), 75-86 (in Polish).

Kotarbiński, T. (1975). Traktat o dobrej robocie. Wrocław: Ossolineum.

Kuhn, T.S . (1962). The structure of scientific revolution. Chicago: University of Chicago Press.

Loudon, K. C., \& Loudon, J.P. (2010). Management information systems. New Jersey: Prentice-Hall.

Markus, L., Majchrzak, A., \& Gasser, L. (2002). A design theory for systems that support emergent knowledge processes. MIS Quarterly, 26, 179-212.

Miles, R.E., \& Snow, C.C. (1992). Caucuses of failure in networking organizations. California Management Review, 34(4), 53-72.

Oliver, A. I., \& Ebers, M. (1998). Networking network studies: an analysis of conceptual configurations in the study of inter-organizational relationship. Organization Studies, 19(4), 549-583.

Rosenberg, B. (2014). Cloud computing. Retrieved from http://www.zoominfo.com/p/BenRosenberg/1870943759

Quinn, J. B. (1992). The intelligent enterprise. NY: The Free Press.

Senge, P. M. The fifth discipline. The art and practice of the learning organization. NY.

Stoner, A. F., \& Wankel C. (2005). Management. Warsaw: PWE (in Polish).

Wilson, B. (2000). Systems: Concepts, methodologies and applications. NY: John Wiley.

Velte, T., Velte, A., \& Elsenpeter, R. (2009). Cloud computing, A practical approach. NY: McGraw-Hill Osborne Media

\section{Biography}

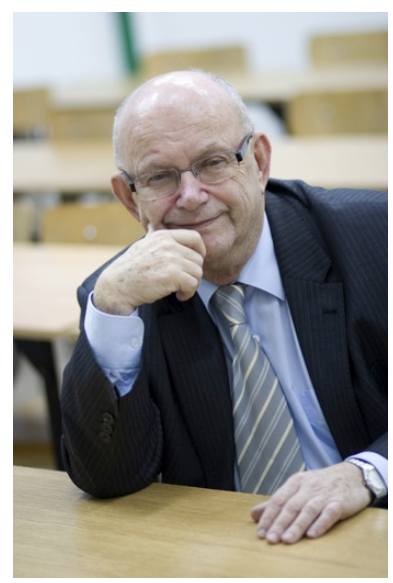

Jerzy Kisielnicki, professor of management, has been the head of the Department of Information Systems in Management and Faculty of Management at Warsaw University Has been the head of the Department of Management at Marketing at the Lazarski University.

His interests are organization and management, systems analysis, management information systems, e-learning, process innovation (reengineering), strategic management, and transition systems organization and management in market economy. Dr. Kisielnicki is a member of the Board of Organization and Management in Polish Academy of Science and is the head of the Scientific Council of Polish Society of Systems Information. He has had about 220 publications. 